\title{
EXPERIMENTAL PRECISION IN CORN TRIALS USING THE PAPADAKIS METHOD
}

\author{
Precisão experimental dos ensaios de milho pelo método de Papadakis
}

\author{
Lindolfo Storck ${ }^{1}$, Sidinei José Lopes², Alberto Cargnelutti Filho², Alessandro Dal’Col Lúcio², Marcos Toebe ${ }^{3}$
}

\begin{abstract}
The objective of this work was to verify whether the use of the Papadakis method in competing corn hybrid trials would lead to modifications in the validity of assumptions for the mathematical model of variance analysis and for experimental precision indicators. To achieve this, corn-grain-yield data from 25 competing corn hybrid trials, performed in a design of complete randomized blocks, were examined. Each trial entailed verification of assumptions, variance analysis, hypothesis tests, statistics to identify experimental precision, and analysis using the Papadakis method. This method improves experimental precision indicators. The assumptions were valid for both analysis types (without Papadakis and with Papadakis). Mean figures for the Fasoulas differentiation index increased from 8.5 to 20.7 and selective precision rose from 0.82 to 0.92 . Trials with three repetitions analyzed using the Papadakis method enabled the identification of superior corn hybrids in relation to grain yield, with $86.5 \%$ precision. To maintain the same precision in conventional analysis, four times the number of repetitions would be necessary.
\end{abstract}

Index terms: Zea mays L., assumptions, precision measurements, spatial analysis.

\section{RESUMO}

Objetivou-se, no trabalho, verificar se há modificações em relação ao atendimento dos pressupostos do modelo matemático da análise de variância e indicadores de precisão experimental, com a aplicação do método de Papadakis, em ensaios de competição de híbridos de milho. Para isso, foram usados os dados de produtividade de grãos de milho de 25 ensaios de competição de híbridos, conduzidos no delineamento blocos completos ao acaso. Em cada ensaio, foram realizadas: a verificação dos pressupostos, a análise de variância, os testes de hipóteses, estatísticas para identificação da precisão experimental e a análise pelo método de Papadakis. O método de Papadakis melhora os indicadores de precisão experimental. Os pressupostos não foram violados para os dois métodos de análise (sem Papadakis e com Papadakis). A média do índice de diferenciação de Fasoulas aumentou de 8,5 para 20,7 e a acurácia seletiva de 0,82 para 0,92. Ensaios com três repetições analisados com o método de Papadakis possibilitam a identificação de híbridos superiores de milho em relação à produtividade de grãos, com $86,5 \%$ de precisão. Para manter a mesma precisão na análise usual seria necessário o quádruplo do número de repetições.

Termos para indexação: Zea mays L., pressupostos, medidas de precisão, análise espacial.

(Received in august 7, 2009 and approved in july 28, 2010)

\section{INTRODUCTION}

Genetic differences between corn hybrids such as grain yield and other characteristics observed in trials are important, as these results may be applied to crop production. Failure to identify the superiority of a hybrid due to the lack of experimental precision in trials has a negative impact on crop yield, since the result of such tests are used to recommend hybrids to be grown by producers.

In order to obtain acceptable levels of experimental precision in trials, the necessary procedures include understanding the soil uniformity from experimental area, establishing a suitable experimental design, defining the number of repetitions and plot sizes, and ensuring uniform management (Gómez \& Gómez, 1984; Steel et al., 1997; Ramalho et al., 2005; Banzatto \& Kronka, 2006; Storck et al., 2006; Catapatti et al., 2008; Oliveira et al., 2009). Appropriate measures taken to guarantee experimental precision are important for determining the credibility of the results of a given trial. Studies show that statistics on selective accuracy, inheritability, coefficient of determination, and F-test values for hybrids are directly related to each other and are more suitable than the coefficient of variation and minimum significant difference, in terms of average percentages, to evaluate experimental precision in competing corn hybrid trials. In addition, class limits established from these statistics are suitable to estimate the degree of experimental precision in competing corn hybrid trials (Cargnelutti Filho \& Storck, 2007, 2009).

\footnotetext{
${ }^{1}$ Universidade Federal de Santa Maria/UFSM - Departamento de Fitotecnia - Avenida Roraima - s/n - Camobi - $97105-900$ - Santa Maria, RS lindolfo@pq.cnpq.br

2Universidade Federal de Santa Maria/UFSM - Departamento de Fitotecnia - Santa Maria, RS

${ }^{3}$ Universidade Federal de Santa Maria/UFSM - Santa Maria, RS
} 
The Papadakis method (Papadakis, 1937) consists of adjusting the values obtained in the plots in accordance with the mean experimental errors between neighboring plots, considered covariate, in order to decrease experimental error variance. The most suitable covariate is the estimate of errors between reference plots and their closest neighbors (to the left, right, front and back) (Cargnelutti Filho et al., 2003).

The use of the Papadakis method for 226 soybean trials, with diverse environments and genetic material, has shown to be efficient at improving experimental precision indicators (Storck et al., 2008, 2009). The method, according to Cargnelutti Filho et al. (2003), provided gains in precision in a study involving five corn trials. The degree of efficiency of the Papadakis method for experiments with different corn hybrids, carried out over a sequence of years in the same experimental area, is still not well known.

The aim of this work was to verify whether the use of the Papadakis method in competing corn hybrid trials would lead to modifications in the validity of assumptions about the mathematical model of variance analysis and experimental precision indicators.

\section{MATERIAL AND METHODS}

Data on corn-grain yield was collected from 25 experiments of competing hybrids-super-early, early, and normal cycles-with a varied number of hybrids per experiment for the crop years 1998/1999 to 2007/2008 (Table 1). All the trials were carried out in the same experimental area, located on the east side of the meteorological station of the Plant Science Department at the Federal University of Santa Maria, in Santa Maria, Rio Grande do Sul, Brazil (latitude $29^{\circ} 42 \mathrm{~S}$, longitude $53^{\circ} 49 \mathrm{~W}$ and $95 \mathrm{~m}$ altitude). The trials featured randomized block design and three repetitions. The experimental units were comprised of two 5-m-long rows, spaced $80 \mathrm{~cm}$ centimeters apart.

Variance analyses were conducted on the grain yield data from each experiment, with hypothesis tests at $5 \%$ probability for blocks and hybrids. Estimates were made of the relative efficiency of the use of blocks, the average per hybrid, the overall average $(\hat{\mathrm{m}})$, and the amplitude $(\mathrm{H})$ between averages. The coefficient of variation $(\mathrm{CV})$ and minimum significant difference between hybrids were also estimated, using the Tukey test at $5 \%$ probability (D), $D=q_{\left(\alpha ; I ; D F_{E}\right)} \sqrt{M S_{E} / J}$, in which $q_{\left(\alpha ; I ; D F_{E}\right)}$ is the Tukey test table value, $\mathrm{I}$ is the number of hybrids, $\mathrm{DF}_{\mathrm{E}}$ is the degree of freedom of the error, $\mathrm{MS}_{\mathrm{E}}$ is the estimate of experimental error (Mean Square Error), and $\mathrm{J}$ is the number of repetitions (blocks). The minimum significant difference between hybrids, according to the Tukey test, expressed as a percentage of the average (MSD), was obtained for $\mathrm{MSD}=100 \mathrm{D} / \hat{\mathrm{m}}$. To assess experimental precision, the Fasoulas differentiation index (FDI) (Fasoulas, 1983) was also calculated, which is estimated in the expression $\mathrm{FDI}=200 \sum_{\mathrm{i}=1}^{\mathrm{n}} \mathrm{m}_{\mathrm{i}} /[\mathrm{n}(\mathrm{n}-1)]$, where $\mathrm{n}$ is the number of cultivars in the trial and $m_{i}$ is the number of averages that the i-th hybrid statistically exceeds after applying the Tukey test.

The value of the statistic $\mathrm{R}^{2}$ was established by the coefficient of determination (Cargnelutti Filho \& Storck, 2007), expressed by $\mathrm{R}^{2}=\mathrm{MS}_{\mathrm{g}} /\left(\mathrm{MS}_{\mathrm{g}}+\mathrm{MS}_{\mathrm{E}}\right)$, where $\mathrm{MS}_{\mathrm{g}}$ is the squared mean of hybrids. In addition, selective accuracy (SA) was estimated as follows: $\mathrm{SA}=(1-1 / \mathrm{F})^{1 / 2}$, in which $\mathrm{F}$ is the $\mathrm{F}$ test value for hybrids (Resende \& Duarte, 2007; Cargnelutti Filho \& Storck, 2009).

Considering the evaluations in each block as measurements performed on the same individual (hybrid), the intra-class correlation coefficient for hybrids, or repeatability coefficient (variance analysis method), was estimated: $\hat{\rho}_{g}=\hat{\sigma}_{g}^{2} /\left(\hat{\sigma}^{2}+\hat{\sigma}_{g}^{2}\right)$, in which $\hat{\sigma}_{g}^{2}=\left(M S_{g}-M S_{E}\right) / J$ and $\hat{\sigma}^{2}=M S_{E}$. The minimum number of measurements (repetitions $=$ blocks $=\mathrm{J}$ ) required to predict the real value of the individuals (hybrids), based on determination or pre-established precision $\left(\mathrm{R}^{2}\right)$, was obtained in accordance with Cruz \& Regazzi (1997). In other words, the J value for one data point $R^{2}$ was: $J\left(R^{2}\right)=\left(1-\widehat{\rho}_{g}\right) R^{2} / \widehat{\rho}_{g}\left(1-R^{2}\right)$.

Error values for each experimental unit were estimated by considering the randomized block design (observed value minus overall mean, less block and hybrid effects). The error values were used to apply the normality Lilliefors test (Sprent $\&$ Smeeton, 2007). For the random error test, or sequence test (Sprent \& Smeeton, 2007), the number of sequences of positive and negative errors followed a pre-established path. The test statistic, equal to the number of times in which a sign is changed by another as it passes through the sequence of errors in the experimental plots, was tested for approximation to a standard normal distribution. The Bartlett test (Steel et al., 1997) was applied to verify the homogeneity of the error variance between hybrids. The additivity of the mathematical model was verified using the non-additivity test of the Tukey mathematical model (Snedecor \& Cochran, 1989). The hypotheses about the assumptions (normality, randomness, homogeneity, and additivity) were tested at 5\% probability.

The errors were also estimated considering the completely randomized design (value observed minus overall mean and the hybrid effect). Using these values, the mean error for each experimental unit was estimated as the mean between the error of the unit in question and the errors of its existing, neighboring experimental units (to its right, left, 
front, and back) (Cargnelutti Filho et al., 2003). The value for the mean error was deemed a covariate for the purpose of covariance analysis, in accordance with the completely randomized design (Steel et al., 1997; Storck et al., 2008), which corresponds to the use of the Papadakis (1937) method.

Covariate values were submitted to variance analysis, in accordance with the random block design, and tested against the assumptions for normality, randomness, and homogeneity of variance.

The covariance analysis, with hypothesis tests for the effects of the covariate and adjusted hybrids, was carried out in accordance with Steel et al. (1997), and with estimates made of: amplitude $(\mathrm{H})$ between means of adjusted hybrids, CV, D, MSD, FDI, R ${ }^{2}, \mathrm{SA}, \hat{\rho}_{g}$, and $\mathrm{J}\left(\mathrm{R}^{2}\right)$.
The relative efficiency of covariate use in relation to the use of randomized block design was also estimated, and assumption hypotheses were tested (normality, randomness, and homogeneity of variance) regarding error in this model and the parallelism between hybrids, with respect to the covariate response (Seber, 1976). For all calculations, a specific program in Pascal language was prepared and compiled.

\section{RESULTS AND DISCUSSSION}

Over the ten years in which the 25 trials were conducted in the same experimental area, the average crop yield was $7.49 \mathrm{t} \mathrm{ha}^{-1}$, ranging between 4.42 and $10.86 \mathrm{t} \mathrm{ha}^{-1}$ (Table 1). These results reflect annual variations in both

Table 1 - Corn grain yield $\left(\mathrm{t} \mathrm{ha}^{-1}\right)$, mean square of block $\left(\mathrm{MS}_{\mathrm{B}}\right)$, hybrid $(\mathrm{MSg})$, and error $\left(\mathrm{MS}_{\mathrm{E}}\right)$, without using the Papadakis method vs. year of harvest, cycle, and number (I) of hybrids evaluation in trials in Santa Maria.

\begin{tabular}{|c|c|c|c|c|c|c|c|}
\hline Trial & Year & Cycle & I & $\mathrm{t} \mathrm{ha}^{-1}$ & $\mathrm{MS}_{\mathrm{B}}$ & $\mathrm{MSg}$ & $\mathrm{MS}_{\mathrm{E}}$ \\
\hline 1 & 1999 & Super-early & 25 & 4.496 & 1.67721 & 1.28900 & 1.01056 \\
\hline 2 & 1999 & Early & 30 & 5.176 & $4.76420 *$ & $1.61869 *$ & 0.40778 \\
\hline 3 & 1999 & Normal & 9 & 4.420 & $6.19961 *$ & 1.52998 & 0.68687 \\
\hline 4 & 2000 & Super-early & 20 & 7.642 & $4.97857 *$ & $2.78139 *$ & 1.43760 \\
\hline 5 & 2000 & Early & 23 & 6.088 & 1.99256 & $2.76772 *$ & 0.79791 \\
\hline 6 & 2000 & Normal & 7 & 7.334 & 0.97025 & $5.00859 *$ & 0.60950 \\
\hline 7 & 2001 & Super-early & 16 & 6.977 & 0.99758 & $3.75900 *$ & 0.75560 \\
\hline 8 & 2001 & Super-early & 16 & 7.578 & 1.42122 & $7.64464 *$ & 2.12870 \\
\hline 9 & 2001 & Early & 30 & 6.756 & $9.36463^{*}$ & $1.82053^{*}$ & 0.38712 \\
\hline 10 & 2001 & Early & 30 & 8.075 & $2.81265^{*}$ & $2.31700 *$ & 0.69406 \\
\hline 11 & 2002 & Super-early & 13 & 7.681 & 0.48530 & $2.53815^{*}$ & 0.92230 \\
\hline 12 & 2002 & Tardio & 9 & 6.849 & $1.94945^{*}$ & $1.85935^{*}$ & 0.45927 \\
\hline 13 & 2002 & Early & 30 & 6.234 & 0.29933 & 1.30631 & 0.82998 \\
\hline 14 & 2003 & Early & 27 & 6.020 & 0.54967 & $5.24625^{*}$ & 0.91705 \\
\hline 15 & 2003 & Super-early & 18 & 7.807 & 0.35031 & 2.24161 & 2.72520 \\
\hline 16 & 2004 & Super-early & 16 & 8.053 & 0.69133 & $7.38776^{*}$ & 0.45024 \\
\hline 17 & 2004 & Early & 27 & 7.051 & 0.51194 & $5.91616^{*}$ & 0.74537 \\
\hline 18 & 2005 & Super-early & 12 & 8.511 & $16.49854^{*}$ & $4.49481 *$ & 0.48586 \\
\hline 19 & 2005 & Early & 30 & 8.851 & $10.88618^{*}$ & 2.48824 & 1.79767 \\
\hline 20 & 2006 & Early & 26 & 8.588 & $11.27053^{*}$ & $3.01701 *$ & 0.62697 \\
\hline 21 & 2006 & Super-early & 23 & 8.921 & $4.97406^{*}$ & $2.84149 *$ & 1.31779 \\
\hline 22 & 2007 & Super-early & 12 & 10.861 & 0.14187 & $5.98222 *$ & 0.40433 \\
\hline 23 & 2007 & Early & 40 & 10.047 & 1.43370 & $3.53743 *$ & 2.18715 \\
\hline 24 & 2008 & Super-early & 15 & 8.391 & $1.49884^{*}$ & $3.78845^{*}$ & 0.37014 \\
\hline 25 & 2008 & Early & 60 & 8.912 & $4.93392 *$ & $4.68578^{*}$ & 0.51717 \\
\hline
\end{tabular}

* Significant for $\mathrm{F}$ test at $5 \%$ probability. 
the environment and the composition of hybrids in the trials, as each hybrid was assessed, in general, for two consecutive years. In 12 trials $(48 \%)$, the effect of blocks was significant (Table 1), which also indicates that variability was controlled in the experimental area.

The variation among hybrids, significant in $80 \%$ of experiments, and the occurrence of flaws in the assumptions (normality, randomness, homogeneity of variance and mathematical model additivity) (Table 2) was close to that found in the study of 307 corn trials (Marques et al., 2000), which does not constitute a reason to restrict the interpretation of results.

In all trials, the covariant (mean error in neighboring experimental units) was not significantly dependent on the hybrid effect (Table 2). This fact shows that the differences between the treatments was independent of covariant values, a prerequisite to proceed with analyzing covariance and adjusting hybrid averages in line with the covariant means (Steel et al., 1997). Furthermore, the assumptions of randomness and homogeneity of variance were validated. However, a lack of covariant normality was observed in five trials (20\%), more than that observed $(8 \%)$ for the variable grain yield error; this difference has also been seen in soybean trials (Storck et al., 2008). The blocks were heterogeneous in relation to the covariant in $60 \%$ of trials, higher than that observed $(38.9 \%$ of trials) in soybeans (Storck et al., 2008).

Mean relative efficiency in the use of blocks was $126.6 \%$ (Table 3), due to the $48 \%$ of trials with heterogeneous blocks. For soybean trials, Storck et al. (2008) calculated mean relative efficiency of $134.5 \%$ in just $28.8 \%$ of trials with heterogeneous blocks. This may be explained by the greater number of hybrids per block in the corn trials (Table 1) when compared with those for soybeans.

The application of the Papadakis method raised the proportion of trials with significant hybrid effect from $80 \%$ to $96 \%$ (Table 2); in $96 \%$ of the trials, the covariant effect was also significant. The use of the Papadakis method improved all experimental precision measures: reducing the mean coefficient of variation (CV) from $12.9 \%$ to $8.9 \%$; reducing the mean minimum significant difference among hybrids, according to the Tukey test, from $2.90 \mathrm{t} \mathrm{ha}^{-1}$ to $2.03 \mathrm{tha}^{-1}$; reducing the mean minimum significant difference among hybrids, according to the Tukey test and expressed as a percentage of the mean (MSD), from $40.1 \%$ to $27.8 \%$; increasing mean selective accuracy (SA) from 0.819 to 0.925 ; increasing the mean Fasoulas differentiation index (FDI) from 8.49 to 20.73; and increasing the model's coefficient of determination from $76.9 \%$ to $86.5 \%$ (Table 3). Similar variations in these precision measures were obtained for 226 soybean trials (Storck et al., 2008).

Table 2 - Number of cases in which different null hypotheses were rejected at $5 \%$ probability for analysis of variance (ANOVA), for covariant of Papadakis method, and for analysis using the Papadakis method, in 25 trials of competing corn hybrids.

\begin{tabular}{lccc}
\hline Hypothesis about & ANOVA & Covariant & Papadakis \\
\hline Blocks & $12(48 \%)$ & $15(60 \%)$ & - \\
Hybrids & $20(80 \%)$ & 0 & $24(96 \%)$ \\
Covariant & - & - & $24(96 \%)$ \\
Normality (N) & 2 & 5 & 4 \\
Randomness (Al) & 0 & 0 & 0 \\
Homogeneity (H) & 1 & 1 & 2 \\
Additivity (Ad) & 2 & - & - \\
N and Al & 0 & 0 & 0 \\
N and H & 0 & 1 & 0 \\
N and Ad & 1 & - & - \\
Al and H & 0 & 0 & 0 \\
Al and Ad & 0 & - & - \\
H and Ad & 0 & - & - \\
Parallelism of covariant & - & - & $10^{*}$ \\
\hline
\end{tabular}

* Number of trials with non-parallel responses in terms of covariant. 
Table 3 - Mean amplitude (Ampl.) and coefficient of variation (CV) for different estimated statistics in trials of competing corn hybrids (grain yield, $\mathrm{t} \mathrm{ha}^{-1}$ ) related to the use of the Papadakis method.

\begin{tabular}{|c|c|c|c|c|c|c|}
\hline \multirow{2}{*}{ Statistics $^{1}$} & \multicolumn{3}{|c|}{ Without Papadakis } & \multicolumn{3}{|c|}{ With Papadakis } \\
\hline & Mean & Ampl. & $\mathrm{CV}(\%)$ & Mean & Ampl. & $\mathrm{CV}(\%)$ \\
\hline $\mathrm{RE}(\%)$ & 126.62 & 280.00 & 44.7 & - & - & - \\
\hline $\operatorname{Mean}\left(\mathrm{t} \mathrm{ha}^{-1}\right)$ & 7.4928 & 6.4407 & 20.4 & - & - & - \\
\hline $\mathrm{CVe}(\%)$ & 12.9 & 16.5 & 33.3 & 8.9 & 15.5 & 37.2 \\
\hline SA & 0.819 & 0.504 & 17.2 & 0.925 & 0.243 & 5.9 \\
\hline D Tukey & 2.9049 & 3.2427 & 31.9 & 2.0322 & 3.5857 & 41.0 \\
\hline Amplitude & 4.0378 & 5.5103 & 33.8 & 4.0488 & 5.7169 & 33.4 \\
\hline $\operatorname{MSD}(\%)$ & 40.1 & 53.5 & 33.4 & 27.8 & 48.2 & 37.2 \\
\hline FDI & 8.49 & 34.85 & 118.5 & 20.73 & 52.38 & 70.8 \\
\hline $\mathrm{R}^{2}(\%)$ & 76.9 & 49.2 & 16.8 & 86.5 & 49.7 & 12.1 \\
\hline Beta & - & - & - & 1.3429 & 1.3773 & 18.3 \\
\hline $\operatorname{REP}(\%)$ & - & - & - & 138.1 & 221.4 & 44.3 \\
\hline$\hat{\rho}_{g}$ & 0.4846 & 0.7529 & 46.5 & 0.6648 & 0.8929 & 30.5 \\
\hline $\mathrm{J}\left(\mathrm{R}^{2}=80 \%\right)$ & 8.2 & 42.8 & 126.7 & 2.1 & 9.6 & 94.2 \\
\hline
\end{tabular}

${ }^{1} \mathrm{RE}=$ relative efficiency of the use of blocks; $\mathrm{CVe}=$ experimental error coefficient of variation; $\mathrm{SA}=$ selective accuracy; $\mathrm{D}$ Tukey = minimum significant difference using Tukey test (5\%); Amplitude $=$ amplitude between means; MSD $=\mathrm{D}$ Tukey as a percentage of the mean; FDI = Fasoulas differentiation index $\mathrm{R}^{2}=$ model's coefficient of determination; Beta = effect of covariant, coefficient of linear regression; RE P = relative efficiency of the use of the Papadakis method; $\hat{\rho}_{g}=$ coefficient of repeatability; $\mathrm{J}\left(\mathrm{R}^{2}=80 \%\right)=$ number of repetitions related to establishment or precision of $80 \%$.

Notably, selective accuracy (SA), an experimental precision measure appropriate for use in corn trials (Cargnelutti Filho \& Storck, 2009), showed that precision was very high $(\mathrm{SA} \geq 0.90)$ in $32 \%$ of the trials without the use of the Papadakis method. On the other hand, when the Papadakis was used, very high precision was observed in $76 \%$ of trials, which indicates the importance of using the Papadakis method to improve experimental precision. As well as raising mean selective accuracy, using the Papadakis method also reduced the variation amplitude and coefficient of variation of this precision measure; that is, experimental precision became more homogeneous and higher, which can also be seen in the FDI and $\mathrm{R}^{2}$ precision measures.

On average, the use of the Papadakis method was $38.1 \%$ more efficient than that of the random block design model, as relative efficiency (RE P, Table 3) was equal to $138.1 \%$, with variation of between $53.2 \%$ and $274.6 \%$ and a $\mathrm{CV}$ of $44.3 \%$. Another aspect that favors the Papadakis method is that the error assumptions (normality, randomness, and homogeneity of variance) with the covariance analysis model were not fulfilled in similar proportions to those found when using the random block design model (Table 2).

The mean linear regression coefficient (covariant effect, Beta) was 1.343, with amplitude of 1.377 (Table 3), indicating that grain yield values may vary significantly in $96 \%$ of the trials, upward or downward, with varying intensity in different trials. For every additional unit in the covariant (mean error for neighboring plots), plot value rises $34.3 \%$ (multiplied by 1.343 ), a lower value (1.44) than that obtained for soybean trials (Storck et al., 2008). However, for $60 \%$ of trials, the response (Beta value) was not parallel among the hybrids (Table 2). The lack of parallelism indicates that the hybrids of a given trial experience varying intensities of mean adjustment, depending on the coefficient of regression for each hybrid, with the mean adjustment taking place with the same coefficient of regression for all hybrids. This concern was also reported by Storck et al. (2008) for soybean trials, where parallelism was not observed in $49 \%$ of trials.

In the repeatability analysis, the mean value for the intra-class correlation coefficient $\left(\hat{\rho}_{g}\right)$ estimated using the 
Papadakis method was 0.6648 , and the reduction in the number of repetitions required for a given level of precision was significant. Using the Papadakis method, on average just one-quarter of the number of repetitions was necessary to predict the real individual values (hybrids), based on determination or pre-established precision $\left(\mathrm{R}^{2}=0.80\right)$, when compared to conventional analysis (without using the Papadakis method) (Table 3).

In general practice, three repetitions are performed in corn trials, well under the eight repetitions that would be necessary to show differences existing between hybrids, with $80 \%$ confidence. However, using the Papadakis method, the same confidence level of $80 \%$ may be obtained with just three repetitions, and determination or precision would be $\mathrm{R}^{2}=0.865$.

\section{CONCLUSIONS}

In analyzing grain yields in trials of competing corn hybrids using the Papadakis method, in comparison to the random block design model, it can be seen that the assumptions of normality, randomness, homogeneity and additivity remain valid.

The Papadakis method, compared to the use of the random block model, improved indices of experimental precision measures, and enabled a reduction in the number of repetitions required to predict corn hybrid performance with the same level of precision in relation to grain yield.

Trials involving the conventional three repetitions, analyzed using the Papadakis method, enable the identification of superior corn hybrids in terms of grain yield.

\section{ACKNOWLEDGEMENTS}

The authors wish to express their particular thanks to the National Council for Scientific and Technological Development $(\mathrm{CNPq})$ for their support.

\section{REFERENCES}

\section{BANZATTO, D.A.; KRONKA, S.N. Experimentação}

Agrícola. 4.ed. Jaboticabal: Funep, 2006. 237p.

CARGNELUTTI FILHO, A.; STORCK, L. Estatísticas de avaliação da precisão experimental em ensaios de cultivares de milho. Pesquisa Agropecuária Brasileira, Brasília, v.42, p.17-24, 2007.

CARGNELUTTI FILHO, A.; STORCK, L. Medidas do grau de precisão experimental em ensaios de competição de cultivares de milho. Pesquisa Agropecuária

Brasileira, Brasília, v.44, n.2, p.111-117, 2009.

CARGNELUTTI FILHO, A.; STORCK, L.; LÚCIO, A.D.

Ajustes de quadrado médio do erro em ensaios de competição de cultivares de milho pelo método de Papadakis. Pesquisa Agropecuária Brasileira, Brasília, v.38, p.467-473, 2003.

CATAPATTI, T.R.; GONÇALVES, M.C.; SILVA NETO, M.R.; SOBROZA, R. Tamanho de amostra e número de repetições para avaliação de caracteres agronômicos em milho-pipoca. Ciência e Agrotecnologia, Lavras, v.32, n. 3, p.855-862, maio/jun. 2008.

CRUZ, C.D.; REGAZZI, A.J. Modelos biométricos aplicados ao melhoramento genético. 2.ed. Viçosa, MG: UFV, 1997. 390p.

FASOULAS, A.C. Rating cultivars and trials in applied plant breeding. Euphytica, Wageningen, v.32, p.939-943, 1983.

GÓMEZ, K.A.; GÓMEZ, A.A. Statistical procedures for agricultural research. 2.ed. New York: J. Wiley, 1984. 680 p.

MARQUES, D.G.; STORCK, L.; LOPES, S.J.; MARTIN, T.N. Qualidade dos ensaios de competição de cultivares de milho no Estado do Rio Grande do Sul. Ciência Rural, Santa Maria, v.30, p.381-385, 2000.

PAPADAKIS, J.S. Méthode statistique pour des expériences sur champ. Thessalonike: Institut d'Amélioration des Plantes à Salonique, 1937. 30p. (Bullettin, 23).

OLIVEIRA, R.L.; MUNIZ, J.A.; ANDRADE, M.J.B.de; REIS, R.L.dos. Precisão experimental em ensaios com a cultura do feijão. Ciência e Agrotecnologia, Lavras, v.33, n. 1, p.113-119, jan./fev., 2009.

RAMALHO, M.A.P.; FERREIRA, D.F.; OLIVEIRA, A.C. Experimentação em genética e melhoramento de plantas. 2.ed. Lavras: UFLA, 2005. 322p.

RESENDE, M.D.V.; DUARTE, J.B. Precisão e controle de qualidade em experimentos de avaliação de cultivares. Pesquisa Agropecuária Tropical, Goiânia, v.37, p.182194, 2007. 
SEBER, G.A.F. Linear regression analysis. NewYork: J. Wiley, 1976. 465p.

SNEDECOR, G.W.; COCHRAN, W.G. Statistical methods. 8.ed. Ames: Iowa State University, 1989. 503p.

SPRENT, P.; SMEETON, N.C. Applied nonparametric statistical methods. 4.ed. Boca Raton: Chapman \& Hall, 2007. 530p.

STEEL, R.G.D.; TORRIE, J.H.; DICKEY, D.A. Principles and procedures of statistics: a biometrical approach. 3.ed. New York: McGraw Hill Book, 1997. 666p.
STORCK, L.; CARGNELUTTI FILHO, A.; LÚCIO, A.D.; LOPES, S.J. Método de Papadakis e número de repetições em experimentos de soja. Ciência Rural, Santa Maria, v.39, p.977-982, 2009.

STORCK, L.; GARCIA, D.C.; LOPES, S.J.; ESTEFANEL, V. Experimentação vegetal. 2.ed. Santa Maria: UFSM, 2006. 198p

STORCK, L.; STECKLING, C.; ROVERSI, T.; LOPES, S.J. Utilização do método de Papadakis na melhoria da qualidade experimental de ensaios com soja. Pesquisa Agropecuária Brasileira, Brasília, v.43, n.5, p.581-587, 2008. 